\title{
Determinants of the State Railway of Thailand's (SRT) Total Quality Management process: SEM analysis
}

\author{
Tanin Sivalai \\ Faculty of Administration and Management, \\ King Mongkut's Institute of Technology Ladkrabang (KMITL) \\ Thailand \\ 55671156@kmitl.ac.th \\ Nuttawut Rojniruttikul \\ Faculty of Administration and Management, \\ King Mongkut's Institute of Technology Ladkrabang (KMITL) \\ Thailand \\ krnuttaw@kmitl.ac.th
}

\begin{abstract}
Dropping from the peak of 88 million passengers back in 1994, Thailand's state railway system today is transporting less than $50 \%$ of its maximum. Operations run at a loss, with infrastructure and aged equipment contributing to significant delays and a continuing loss of passengers. In late 2017 however, a new 20-year, \$US81.57 billion plan was proposed to save the SRT from its downward spiral. The researchers therefore undertook a study to survey 500 Thai state railway (SRT) civil servants. Each was given a 5-level Likert-type agreement scale questionnaire, containing 51 items concerning their personal characteristics, their attitudes, human resource management processes, the use of the balanced scorecard for improvement, their perspectives on SRT's organizational culture, and the SRT's total quality management program. LISREL 9.1 was used to conduct a confirmatory factor analysis (CFA) and then structural equation model (SEM) was applied to analyze the results. The results have determined that organizational culture had the greatest impact on total quality management, followed by attitudes, human resource management, and finally, the balanced scorecard. It is also interesting to note that the surveyed SRT staff consider organizational change as the most important aspect in improving efficiency, while staff evaluation and reward system were rated as least effective for total quality management.
\end{abstract}

Keywords: attitudes, balanced scorecard (BSC), human resource management, organizational culture, total quality management, State Railway of Thailand

JEL Classification: L32, L38, L51, L88 


\section{INTRODUCTION}

The State Railway of Thailand (SRT) has been operating continuously since 1890. However, in the recent decades there has been a significant and ongoing decline in both passengers and revenue. In 1994, SRT passenger traffic peaked at 88 million passengers per year (Ganjanakhundee, 2016), which in 2016 dropped to 44 million passengers. Recent studies have stated that change is critical, but populist programs and aging equipment/infrastructure have significantly slowed the wheels of change (Asian Development Bank, 2014; Sornsaruht \& Deebhijarn, 2016). Personnel policies and organizational bureaucracy have also been stated to be at the root of the problems.

One of the possible reasons for the continual decline in SRT ridership has been the widespread safety speed restrictions placed on the expiring infrastructure and aged equipment. This has resulted in the SRT becoming uncompetitive against other transportation modes (buses, vans, low-cost airlines etc.). Confirmation of this comes from the recent Asian Development Bank (2014) study, in which the main negatives expressed by passengers were SRT punctuality and delays. As the SRT generates $65 \%$ of its revenue from passenger traffic, this has become a significant problem.

In the attempt to correct numerous and unprofitable SRT operations, in late 2017 Thailand's Office of Transport and Traffic Policy and Planning released a 20-year master plan for rail development estimated at more than 2.7 trillion baht (\$US 81.57 billion). The plan is set to be divided into three periods - from 2017 to 2036. Within each time segment, there are plans for 2,777 kilometers of double-track work, the construction of 2,457 kilometers of standard-gauge lines for high-speed trains, network electrification, and the development of intermodal rail freight terminals (Smith, 2017).

Rational for this significant investment comes from various studies which have estimated that Thailand's total logistics value is at US $\$ 85.9$ billion as of 2016, 7.5\% up from the 2015 level (Srimalee, 2017). This is also equal to $14 \%$ of Thailand's GDP. This figure consists of $7 \%$ in transportation costs, $6 \%$ in inventory/warehousing costs, and $1 \%$ in management costs. As a solution to these comparatively high costs, developing Thailand's transportation infrastructure - and the rail system, in particular - has been stated by the acting officials as the way to reduce logistics costs (Srimalee, 2017).

Logistics costs in Thailand however, are not cheap when compared to Thailand's ASEAN neighbors Malaysia and Singapore, as both countries have overall logistics costs below 10\% of GDP. Reduction of costs is therefore a primary motivation in rail investment, as railway transport benefits include high carrying capacity, lower weather influences, and lower energy consumption (Tseng, Yue \& Taylor, 2005).

Additionally, this expansion and upgrade has also been stated to facilitate the establishment of special economic zones (SEZs), to boost tourism, and assist with local development. Official statements have also indicated that by releasing a long-term vision which places rail at the center of Thailand's transport infrastructure development, investor confidence will be boosted.

The study also identified a significant problem as the SRT moves forward into the $21^{\text {st }}$ century. That is its aging staff and the pension liabilities that must be absorbed. This also raises many issues about the potential loss of expertise in the coming years, and how the replacements will be found (there is presently a hiring freeze) (ThaiPBS, 2018). If replacements are not found, how will junior staff be trained, or will technology replace them?

TQM (total quality management) is a fundamental change in how most enterprises manage their business, but change can often be difficult and time consuming. Therefore, SRT management must lead the total quality initiative, with all employees becoming involved in TQM. Continuous quality improvement is a SRT business imperative, as many experienced employees near retirement age, ongoing education and training become essential for all junior employees and new hires. 
Another significant contribution to the SRT's financial health, and the inability to recover its operational costs over many years, was the populous program of 'free' trains, which ran from 2008 until November 1, 2017. During this period, Thailand's SRT operated an extended network of free trains, or coaches on commercial trains, that offered free seats to $3^{\text {rd }}$ class passengers. According to the Asian Development Bank (2014), there were as many as 164 public service obligation (PSO) trains dedicated to free tickets as well as 8 commercial trains that had carriages reserved for the $3^{\text {rd }}$ class passengers and their free tickets.

Although the government always agreed to reimburse the SRT for the ticket price since the program's inception, the process was anything but smooth, which significantly contributed to the SRT's unprofitability over many years (Sornsaruht \& Deebhijarn, 2016). Reasons for this was the SRT PSO reimbursement process worked as a subsidy mechanism requiring SRT to apply for support based on financial information forecast and traffic statistics. The procedure required very detailed financial data by service, which was beyond the accounting system of SRT to provide (Asian Development Bank, 2014; Sornsaruht \& Deebhijarn, 2016). This system therefore was not satisfactory for either the SRT or the MOF (Ministry of Finance), as it provided SRT with less than full reimbursement for losses incurred, causing further internal cross subsidies within SRT to cover these losses as shown in Table 1.

Table 1

SRT PSO mechanisms - requests and payments*

\begin{tabular}{|l|c|c|c|c|c|}
\hline & $\mathbf{2 0 1 0}$ & $\mathbf{2 0 1 1}$ & $\mathbf{2 0 1 2}$ & $\mathbf{2 0 1 3}$ & $\mathbf{2 0 1 4}$ \\
\hline Requested PSO & $3,717.41$ & $3,795.70$ & $4,159.23$ & $4,530.54$ & $4,851.30$ \\
\hline $\begin{array}{l}\text { Thai government } \\
\text { agreed }\end{array}$ & $2,355.00$ & $2,285.42$ & $2,350.00$ & $2,497.00$ & $2,436.00$ \\
\hline Variance & $1,362.41$ & $1,510.28$ & $1,809.23$ & $2,033.54$ & $2,415.30$ \\
\hline Percentage & 63.35 & 40.21 & 56.50 & 55.11 & 50.21 \\
\hline
\end{tabular}

Note: PSO $=$ public service obligation, $*$ millions of Thai baht, 1 million Thai baht $=\$$ US31,818 (5 March 2018). Source. Sornsaruht and Deebhijarn (2016)

Furthermore, from the perspective of MOF, the PSO system did not achieve their social objective of increasing people's mobility, as many of the PSO services were operating with few passengers. Data shows in 2012, 65 out of 164 PSO trains being operated had less than a 40\% load factor, with ridership declining each subsequent year (Asian Development Bank, 2014). This long-running populist program however, was finally terminated and replaced with a welfare-card system on November 1, 2017 (Free bus, train services, 2017).

\subsection{Research Objectives}

Therefore, given the problematic nature of past SRT performance and its crucial importance to Thailand's economic growth, this study was undertaken. From theory and related literature, the researchers identified five latent variables and 17 observed variables. From these, seven hypotheses were developed in which the interrelationships amongst the variables was analyzed by use of structural equation modeling conducted with LISREL Version 9.1 The primary research instrument was a questionnaire containing a 5point Likert type agreement scale to measure the opinions of the sample group which consisted of 500 SRT civil servants from 12 locations around Thailand. The main latent variables measured in the study included staff attitudes (ATT), human resource management (HRM), the balanced scorecard (BSC), organizational 
culture (OC), and total quality management (TQM). From this process, the following questions were identified:

1. How does SRT staff attitudes affect the SRT's organizational culture and its existing total quality management (TQM) program?

2. How does the SRT's human resource management (HRM) policies, programs, and systems affect the rail system's organizational culture and total quality management (TQM) program?

3. How does implementation of the balanced scorecard (BSC) affect organizational culture (OC) and improve the SRT's total quality management (TQM)?

4. And finally, how does this 128 year old state railway system's organizational culture affect the SRT's current total quality management (TQM) program?

\section{LITERATURE REVIEW}

\subsection{Attitude (ATT)}

Harre and Secord (1973) discussed attitudes as certain regularities in an individual's feelings, thoughts, and predispositions to act toward some aspect of their environment. Arnold, Cooper, and Robertson (1995), defined attitudes as a positive or negative tendency towards the object of the attitude.

Intelligence has always been thought of as a component of attitude, but when emotional intelligence (EQ) first appeared to the masses in 1995, it served as the missing link in a peculiar finding: people with average IQs outperform those with the highest IQs 70\% of the time (Bradberry, 2014). This anomaly threw a massive wrench into what many people had always assumed was the sole source of success-IQ. Decades of research now point to EQ as the critical factor that sets star performers apart from the rest of the pack.

This is consistent with Carmeli (2003), whose research within public organizations, determined that EQ was found to augment positive work attitudes, altruistic behavior, and work outcomes. Furthermore, EQ was found to moderate the effects of work-family conflict on career commitment.

From the above theories and scholars' concepts of attitude (ATT), the following three items were therefore placed into the research framework, which included intelligent quotient $(\mathrm{x} 1)$, emotional intelligence ( $\mathrm{x} 2$ ), and human behavior ( $\mathrm{x} 3$ ). From this, the following hypotheses were developed:

H1: Attitude (ATT) has a direct positive influence on organizational culture (OC).

H2: Attitude (ATT) has a direct positive influence on total quality management (TQM).

\subsection{Human resource management (HRM)}

From a 636-senior executive survey conducted by the Economist Intelligence Unit (2013) concerning present and future HR challenges, $50 \%$ indicated that people management was their greatest concern due to multi-generational workforces with growing cultural diversity. These same executives also voiced serious concern over the current disconnect between the skills fostered by education, and those needed by $21^{\text {st }}$ century workers, and the considerable obstacle this significant problem presents in the coming years (Economist Intelligence Unit, 2013; Reeve, 2016).

In Thailand, Dechawatanapaisal (2005) investigated how HRM practices in 12 large corporations affected professionals' learning capabilities. From the 524 questionnaires used, it was determined that staffing, training, and development were strong enablers. Also, performance appraisal and pay were key aspects as well. Similarly, in Malaysia, it was concluded that in small-medium enterprises (SMEs), human resource management practices had significant and positive impacts on innovation and internal processes, 
as well as a firm's employee learning and growth (Mansouri \& Goher, 2016). Another study from the USA indicated that the most significant factor affecting retention rates was job advancement opportunities (Oladapo, 2014). In Greece, Katou (2012) studied 197 small firms and found that HRM policies were contingent on business strategies (cost, innovation, quality), which then had a positive effect on organizational performance through employee attitudes and employee behaviors.

According to Nigro and Nigro (1984), HRM is the ability to recruit people. HRM is also responsible for the screening of applicants, as well as the recruitment of new staff which meets staffing requirements. It is also the development of individual capabilities, as well as the ability to create a corporate environment in which a person can work towards their full capacity, both in terms of quantity and quality.

From the above theories and scholars' concepts of human resource management (HRM), the following three items were therefore placed into the research framework, which included recruitment and selection (x4), training and development (x5), and evaluation and award (x6). From this, the following hypotheses was developed:

H3: Human resource management (HRM) has a direct positive influence on organizational culture (OC).

H4: Human resource management (HRM) has a direct positive influence on total quality management (TQM).

\subsection{Balanced scorecard (BSC)}

Kaplan and Norton's Balanced Scorecard (BSC) construct has been widely applied as a performance measurement and strategy implementation tool by organizations around the world (Kaplan \& Norton, 2001). Research has revealed that the term "balanced scorecard" may however be understood differently by managers, both within, as well as across organizations (Soderberg, Kalagnanam, Sheehan, \& Vaidyanathan, 2011).

From the original Balanced Scorecard performance measurement discussion (Kaplan \& Norton, 1992), the following items were extracted and adapted for this study. They included:

- How do SRT passengers view SRT staff and operations? (passenger's perspective)

- What must the SRT excel at? (internal perspective)

- Can the SRT continue to improve and create value? (innovation and learning perspective)

- How does the SRT organization perceive the SRT's shareholders? (financial perspective)

From the above theories and scholars' concepts of the balanced scorecard (BSC), the following four items were therefore placed into the research framework, which included internal processes $(x 7)$, organization learning and development (x8), finances (x9), and the customer (x10). From this, the following hypotheses were developed:

H5: Balanced scorecard (BSC) has a direct positive influence on organizational culture (OC).

H6: Balanced scorecard (BSC) has a direct positive influence on total quality management (TQM).

\subsection{Organizational culture (OC)}

In recent decades, organizational culture (OC) has attracted a great number of scholarly studies, with Deal and Kennedy (2000) defining OC as the business environment, values, heroes, rites, and rituals of an organization. Prajogo and McDermott (2005) later defined OC as a general pattern of mindsets, beliefs, and values that members of an organization share in common, and state that $\mathrm{OC}$ is one of the key components of a successful TQM implementation. Similarly, Deshpande, Farley, and Webster (1993), considered OC as the pattern of shared values and beliefs that help individuals understand the organization's functions, which 
thus provides them guidelines for behavior in the organization. It has also been determined that the failure of a TQM implementation is primarily due to the lack of integration of TQM and culture change (Cameron \& Quinn, 2006). Prajogo and McDermott (2005), furthermore contend that OC is one of the key determinants for a successful TQM implementation.

In research concerning OC, Ferreira and Hill (2008) stated that the Competing Values Model (CVM) has remained one of the most adopted approaches for OC assessment, with numerous researchers adopting the mode to classify and assess OC. First introduced by Quinn and Rohrbaugh (1983), the CVM model was later modified in its discovery technique of OC. Instead of seeking for the characteristics of effective organizations, experts were asked to give opinions about effective organizations. Subsequently, the research came up with a consensus that experts share the same implicit theoretical framework (Quinn, 1988), which resulted in the development of the competing values framework (CVF).

From the Quinn (1988) developed CVF, researchers have attempted to identify the types of OC that are most suitable for TQM implementation. Gimenez-Espin, Jiménez-Jiménez, and Martínez-Costa (2013), found that clan culture, adhocracy culture, and the "culture for quality", all had a positive impact on quality management, while hierarchy and market cultures give adverse results. Zu, Robbins, and Fredendall (2009) on the other hand, found that clan and market cultures had a significant effect on TQM practices, while adhocracy and hierarchy were found to have no links to TQM practices. Despite these mixed findings, clan and adhocracy cultures have been widely advocated to be favorable to the successful TQM implementation (Dellana \& Hauser, 1991; Prajogo \& McDermott, 2005), whereas hierarchy and market cultures were often found to have no or negative effects on the TQM implementation (Gimenez-Espin et al., 2013). In addition, it was suggested that no organization is likely to be reflected by a single value system. They instead would be expected to appear in combinations of values, in which some are more dominant than others (Dellana \& Hauser, 1991).

From the above theories and scholars' concepts of organizational culture $(\mathrm{OC})$, the following three items were therefore placed into the research framework, which included organizational characteristics (Y1), adaptation (Y2), and corporate strategy (Y3) (Table 2). From this, the following hypothesis was developed:

$\mathrm{H7}$ : Organizational culture (OC) has a direct positive influence on total quality management (TQM).

\subsection{Total quality management (TQM)}

Total quality management (TQM) for this study consists of a 1972 initiated SRT-wide effort to develop a climate in which the group continuously improves its ability to deliver high-quality services to its passengers. Researchers have referred to TQM as a management tool, philosophy, or set of principles which continuously improves the quality of products and services (Andrle, 1994; Prajogo \& McDermott, 2005).

Andrle (1994) stated that TQM has commonly been believed to be a Japanese management philosophy, but it originated in the US following World War I. The Japanese after World War II, later adopted it as they rebuilt their industries. TQM has therefore flourished in Japan since the early 1950s, evolving and changing somewhat over time. According to Evans (2005), TQM involves six basic management concepts including, customer focus, process orientation, continuous improvement, empowerment and teamwork, management by fact, and visionary leadership.

From the above and other related theories and scholars' concepts of total quality management (TQM), the following four items were therefore placed into the research framework, which included leadership (Y4), strategic planning and data analysis (Y5), human resource management (Y6), and process management (Y6) (Table 2). 


\subsection{Conceptualized model}

Based on the above hypotheses and review of the literature, the researchers have developed Figure 1's conceptual framework, which includes the causal relationships between attitude (ATT), human resource management (HRM), the balanced scorecard (BSC), organizational culture (OC), and total quality management (TQM) (Table 2).

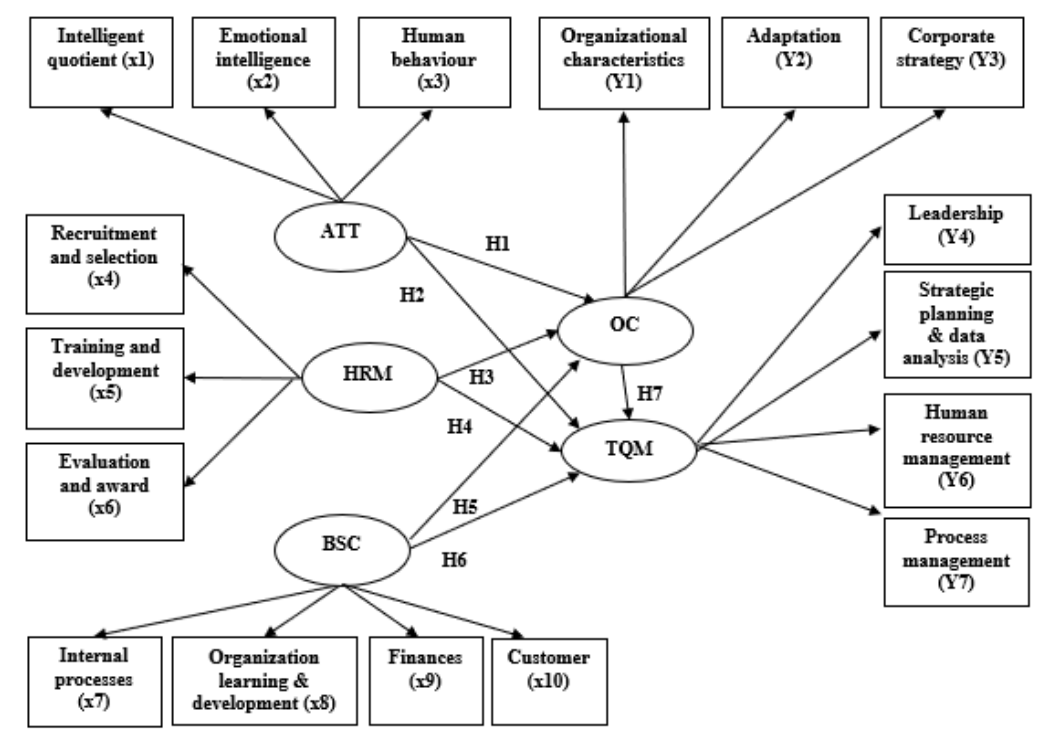

Figure 1. Conceptual framework

Table 2

Latent, observed variables, and related literature

\begin{tabular}{|c|c|c|}
\hline Latent Variables & Observed Variables (17 items) & Related Literature and Theory \\
\hline Attitude (ATT) & $\begin{array}{l}\text { Intelligent quotient }(\mathrm{x} 1) \\
\text { Emotional intelligence }(\mathrm{x} 2) \\
\text { Human behavior }(\mathrm{x} 3)\end{array}$ & $\begin{array}{l}\text { (Arnold et al., 1995; Bradberry, 2014; } \\
\text { Carmeli, 2003; Harre \& Secord, 1973). }\end{array}$ \\
\hline $\begin{array}{l}\text { Human resource } \\
\text { management }(\mathrm{HRM})\end{array}$ & $\begin{array}{l}\text { Recruitment and selection (x4) } \\
\text { Training and development (x5) } \\
\text { Evaluation and award (x6) }\end{array}$ & $\begin{array}{l}\text { (Dechawatanapaisal, 2005; Economist } \\
\text { Intelligence Unit, 2013; Katou, 2012; } \\
\text { Mansouri \& Goher, 2016; Nigro \& Nigro, } \\
\text { 1984; Oladapo, 2014). }\end{array}$ \\
\hline Balanced scorecard (BSC) & $\begin{array}{l}\text { Internal process }(\mathrm{x} 7) \\
\text { Organization learning \& } \\
\text { development }(\mathrm{x} 8) \\
\text { Financial }(\mathrm{x} 9) \\
\text { Customer }(\mathrm{x} 10)\end{array}$ & $\begin{array}{l}\text { (Kaplan \& Norton, 1992, 2001; Soderberg et } \\
\text { al., 2011). }\end{array}$ \\
\hline $\begin{array}{l}\text { Organizational culture } \\
\text { (OC) }\end{array}$ & $\begin{array}{l}\text { Organizational characteristics (Y1) } \\
\text { Adaptation (Y2) } \\
\text { Corporate strategy (Y3) }\end{array}$ & $\begin{array}{l}\text { (Cameron \& Quinn, 2006; Deal \& Kennedy, } \\
\text { 2000; Dellana \& Hauser, 1991; Deshpande et } \\
\text { al., 1993; Ferreira \& Hill, 2008; Gimenez- } \\
\text { Espin et al., 2013; Prajogo \& McDermott, } \\
\text { 2005; Quinn, 1988; Quinn \& Rohrbaugh, } \\
\text { 1983; Zu et al., 2009). }\end{array}$ \\
\hline $\begin{array}{l}\text { Total quality management } \\
\text { (TQM) }\end{array}$ & $\begin{array}{l}\text { Leadership (Y4) } \\
\text { Strategic planning and data analysis } \\
\text { (Y5) } \\
\text { Human resource management (Y6) } \\
\text { Process management (Y6) }\end{array}$ & $\begin{array}{l}\text { (Andrle, 1994; Evans, 2005; Prajogo \& } \\
\text { McDermott, 2005). }\end{array}$ \\
\hline
\end{tabular}




\section{METHODOLOGY}

\subsection{Population and sample}

The sample population or unit of analysis for this research included 500 individuals obtained by multistage sampling from August - October 2017 from 12 SRT related seminars and workshops (Table 3). Using the SRT's personnel directory database of 10,415 employees, the researchers randomly selected $50 \%$ of each unit's employees (12 total units) to invite to a seminar/workshop whose topic focus was concerned with the SRT's TQM process. From the e-mail invitation and subsequent responses, 770 individuals attended the scheduled meetings. This represented a response rate of $14 \%$.

Table 3

SRT seminar and workshop locations and attendance (audited surveys $n=500$ )

\begin{tabular}{|c|c|c|c|c|c|}
\hline Time & $\begin{array}{c}\text { Seminar } \\
\text { day/month/year }\end{array}$ & Seminar location & $\begin{array}{c}\text { Surveys } \\
\text { given* }\end{array}$ & $\begin{array}{c}\text { Surveys } \\
\text { returned }^{*}\end{array}$ & $\begin{array}{l}\text { Audited } \\
\text { surveys* }\end{array}$ \\
\hline 1 & $\begin{array}{l}25 \text { August } 2017 \\
\text { (tryout) }\end{array}$ & $\begin{array}{c}\text { Centara Grand at } \\
\text { Central Plaza Ladprao } \\
\text { Bangkok }\end{array}$ & 120 & 89 & 70 \\
\hline 2 & 31 August 2017 & $\begin{array}{l}\text { The Pine Resort, } \\
\text { Pathumthani }\end{array}$ & 50 & 40 & 37 \\
\hline 3 & 1 September 2017 & $\begin{array}{l}\text { Cholapruek Resort } \\
\text { Nakhon Nayok }\end{array}$ & 100 & 70 & 61 \\
\hline 4 & 8 September 2017 & $\begin{array}{c}\text { Centara Grand at } \\
\text { Central Plaza Ladprao } \\
\text { Bangkok }\end{array}$ & 200 & 180 & 147 \\
\hline 5 & 2 October 2017 & $\begin{array}{l}\text { Housing Fund of } \\
\text { Bangkok }\end{array}$ & 50 & 41 & 31 \\
\hline 6 & 3 October 2017 & $\begin{array}{c}\text { Northern SRT } \\
\text { Maintenance - } \\
\text { Uttaradit Railway } \\
\text { Station } \\
\end{array}$ & 50 & 36 & 29 \\
\hline 7 & 4 October 2017 & SRT Bangkok & 50 & 41 & 26 \\
\hline 8 & 5 October 2017 & $\begin{array}{c}\text { SRT Structural } \\
\text { Division, Bangkok }\end{array}$ & 50 & 30 & 23 \\
\hline 9 & 10 October 2017 & $\begin{array}{l}\text { SRT Information } \\
\text { Systems, Bangkok }\end{array}$ & 50 & 46 & 36 \\
\hline 10 & 11 October 2017 & $\begin{array}{c}\text { Northeastern SRT } \\
\text { Maintenance - Nakhon } \\
\text { Ratchasima Railway } \\
\text { Station }\end{array}$ & 60 & 58 & 50 \\
\hline 11 & 12 October 2017 & $\begin{array}{l}\text { SRT HRM Division, } \\
\text { Bangkok }\end{array}$ & 30 & 19 & 9 \\
\hline 12 & 18 October 2017 & $\begin{array}{c}\text { SRT Assets } \\
\text { Management Division, } \\
\text { Bangkok }\end{array}$ & 80 & 73 & 51 \\
\hline \multicolumn{3}{|c|}{$\begin{array}{c}\text { Note: } * \text { Try-out survey not included in total numbers. } \\
\text { Totals }\end{array}$} & 770 & 545 & 500 \\
\hline
\end{tabular}

The research method used a 51-item instrument to assess the five constructs in the TQM model. All questionnaire items used a 5-point agreement scale response format. 


\subsection{Reliability}

Seven experts determined the reliability of the questionnaire so as to ensure that the responses collected through the instrument were reliable and consistent. The seven experts included four deputy governors of the SRT, and three professors in engineering, innovation, and business administration/research.

A trial assessment of 70 questionnaires was conducted prior to the actual survey to determine questionnaire reliability and consistency (Table 3). The 70 collected and audited questionnaires were independent of the 500 collected for the final analysis. The reliability value was calculated by using Cronbach's $\alpha$ to ensure internal consistency within the items. According to Best and Kahn (2003), when interpreting Cronbach's Alpha $(\alpha)$, a value of $\geq 0.70$ reflects good reliability. According to the pre-test, Cronbach's Alpha $(\alpha)$ averaged $\mathbf{0 . 9 8 8}$, indicating excellent reliability (George \& Mallery, 2010; Hair, Hult, Ringle \& Sarstedt, 2016).

Furthermore, the survey questionnaire was divided into two parts, with Part 1 consisting of six items concerning the SRT's civil service member's personal information, while Part 2 consisted of the actual questionnaire concerning the employee's views about the survey items. For this, Part 2 measured 51 items and was divided into five parts, with attitude (ATT) consisting of 9 items, human resource management (HRM) with 9 items, the balance scorecard (BSC) with 12 items, organizational culture (OC) with 9 items, and total quality management (TQM) with 12 items. Scale measurement made use of a 5-level, Likert type agreement scale, with 1 indicating SRT staff's disagreement with the item's statement, while 5 indicated the SRT staff member strong agreement with the item's statement.

\subsection{Statistical analysis}

The researchers made use of the survey method for data collection, and for the analysis of the hypotheses and their inter-relationships, Lisrel (linear structural relations) 9.1 software was used (Jöreskog, Olsson, \& Fan, 2016). Measurement and data collection implies an evaluation of the measurement model, which for the study included: 1) the individual item reliabilities, 2) the model's convergent validity, and 3) discriminant validity.

Item reliability was examined by looking at the loadings, or correlations, of each indicator on its respective construct. For reflective indicators, it is generally accepted that items must have a factorial load (ג) of 0.707 or above, and all values have are statistically significant $(|t| \geq 1.96)$, representing convergent validity of scales. This threshold implies that there is more variance shared between the measures and their constructs than there is in error variance. Reliability for the derived scale scores was also measured via internal consistency coefficient $\alpha$.

\subsection{Qualitative data analysis}

According to Mertler (2016), in education research if population size is around 1,500, a sample size of 300 is adequate. Also, beyond a certain point $(\mathrm{n}=5,000)$, the population size becomes irrelevant and a sample size of 400 will be adequate. Increasing the size of the sample beyond this point is not critical, but doing so will increase the confidence with which the researcher can generalize results. Therefore, as the study obtained 500 audited questionnaires, the sample was judged to be sufficiently reliable.

\subsection{Confirmatory factor analysis (CFA)}

To access the measurement model, a confirmatory factor analysis (CFA) was used followed by structural equation modeling (SEM) to examine the general fit of the proposed model with data, and to identify the overall relationships among these constructs (Fan et al., 2016). Wong (2013) also noted that for 
marketing research, a significance level of $5 \%$, a statistical power of $80 \%$, and $\mathrm{R}^{2}$ values of at least 0.25 are considered normal. Standard modelling accepts the proposed model if the $p$ value is higher than 0.05 , and if the $\mathrm{x}^{2} / \mathrm{df}$ ratio is less than two (Byrne, Shavelson, \& Muthén, 1989; Ullman, 2001). Additionally, another common reported goodness-of-fit (GoF) statistic is to use the root mean square error of approximation (RMSEA) as a measure of GoF in SEMs (Chen, Curran, Bollen, Kirby, \& Paxton, 2008), and to measure the discrepancy per degree of freedom (df) (Hu \& Bentler, 1999). Also, Hooper et al. (2008) indicated that items with low multiple $\mathrm{R}^{2}$ values $(\leq 0.20)$ should be removed from an analysis as this is an indication of very high levels of error. Hair et al. (2016), used higher criteria and suggested that the $\mathrm{R}^{2}$ values should be greater than 0.25 .

\section{EMPIRICAL RESULTS AND DISCUSSION}

\subsection{Respondents' characteristics $(n=500)$}

From the final sample of 500 SRT civil service employees (Table 4), it was determined that $74.60 \%$ were male, and $25.40 \%$ were female. From the survey's results, the majority, or $41.20 \%$ were 51 years or older.

Table 4

Respondents' characteristics $(n=500)$

\begin{tabular}{|c|c|c|}
\hline Gender & Frequency & $\%$ \\
\hline Male & 373 & 74.60 \\
\hline female & 127 & 25.40 \\
\hline Total & 500 & 100 \\
\hline \multicolumn{3}{|l|}{ Age } \\
\hline 20 years old or less & 2 & 0.40 \\
\hline $21-30$ years old & 71 & 14.20 \\
\hline $31-40$ years old & 108 & 21.60 \\
\hline 41-50years old & 113 & 22.60 \\
\hline 51 years or older & 206 & 41.20 \\
\hline Total & 500 & 100 \\
\hline \multicolumn{3}{|l|}{ Marital status } \\
\hline Single & 152 & 30.40 \\
\hline Married & 331 & 66.20 \\
\hline Other & 17 & 3.40 \\
\hline Total & 500 & 100 \\
\hline \multicolumn{3}{|l|}{ Education level } \\
\hline Junior high school or less & 1 & 0.20 \\
\hline $\begin{array}{l}\text { High school diploma/vocational } \\
\text { certificate }\end{array}$ & 79 & 15.80 \\
\hline High vocational certificate & 55 & 11.00 \\
\hline Undergraduate degree & 298 & 59.60 \\
\hline Graduate degree & 67 & 13.40 \\
\hline Total & 500 & 100 \\
\hline \multicolumn{3}{|l|}{ Civil Service Rank } \\
\hline CS5 or lower & 63 & 12.60 \\
\hline CS 6-7 & 177 & 35.40 \\
\hline CS 8-9 & 201 & 40.20 \\
\hline CS 10 or higher & 59 & 11.80 \\
\hline Total & 500 & 100 \\
\hline Experience & & \\
\hline
\end{tabular}




\begin{tabular}{|l|c|c|}
\hline 10 years or less & 107 & 21.40 \\
\hline $11-20$ years & 80 & 16.00 \\
\hline $21-30$ years & 153 & 30.60 \\
\hline 31 or more & 160 & 32.00 \\
\hline Total & 500 & 100 \\
\hline
\end{tabular}

\subsection{Respondents' information}

Table 5 also shows that the factors that affect SRT civil service staff attitudes (ATT), human resource management (HRM), the balanced scorecard (BSC), organizational culture (OC), and total quality management (TQM). Interpreted results from the 5-point Likert style agreement survey ranged from 3.12 -3.27 (Best \& Kahn, 2003).

$\bar{x}$ and S.D. and survey interpretation

\begin{tabular}{|l|c|c|c|}
\hline Latent Variables & $\bar{x}$ & S.D. & Interpretation \\
\hline Attitudes (ATT) & 3.27 & 0.75 & Somewhat. \\
\hline Human resource management (HRM) & 3.12 & 0.80 & Somewhat. \\
\hline Balance scorecard (BSC) & 3.26 & 0.74 & Somewhat. \\
\hline Organizational culture (OC) & 3.15 & 0.76 & Somewhat. \\
\hline Total quality management (TQM) & 3.18 & 0.73 & Somewhat. \\
\hline
\end{tabular}

Note. $\bar{x}=$ the standard mean, S.D. $=$ Standard Deviation.

\subsection{Confirmatory factor analysis (CFA) results}

After a review of research documents and relevant theory, a CFA analysis was used to test the interrelationships of the internal and external variables (Figure 2 and Figure 3) (Andre, 2017). By analyzing the CFA items with the LISREL 9.1 program, $\chi 2$ was determined to not be statistically significant $(p>0.05)$, $\chi^{2} / \mathrm{df}$ was $\leq 2.00$, RMSEA $\leq 0.05$, and standardized root mean square residual (SRMR) $\leq 0.05$. The goodness-of-fit statistic (GoF) was also indicated to be 0.998 , which shows good fit as it is higher than 0.90 (Hooper et al., 2008). The value for the adjusted goodness-of-fit index (AGFI) was 0.98 , which indicates a well-fitting model as its value is also greater than 0.90 . 


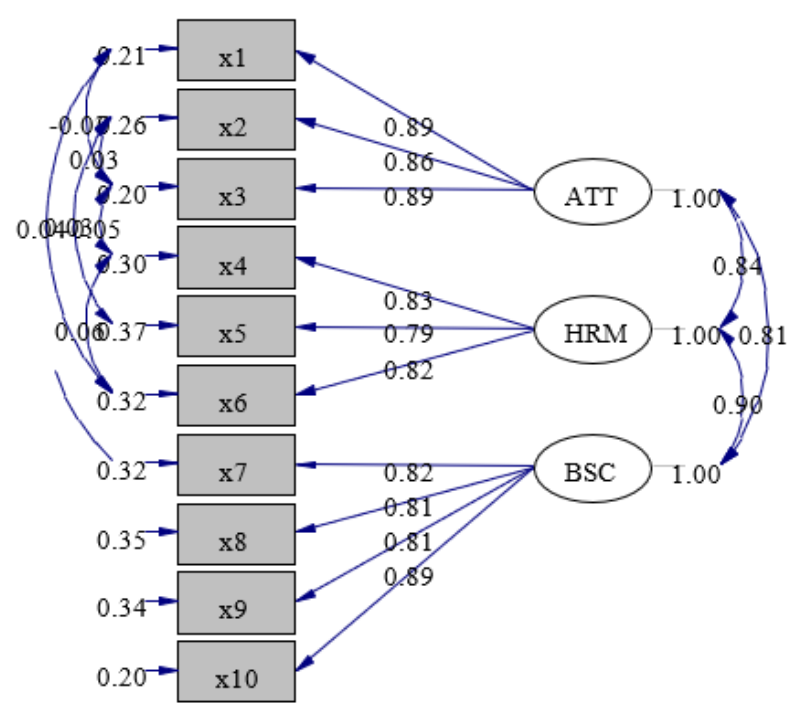

Figure 2. CFA of external latent variables ATT, HRM, \& BSC $(n=500)$ Note: Chi-Square $(\chi 2)=5.42, \mathrm{df}=15, p$ value $=0.98788, \mathrm{RMSEA}=0.000$.

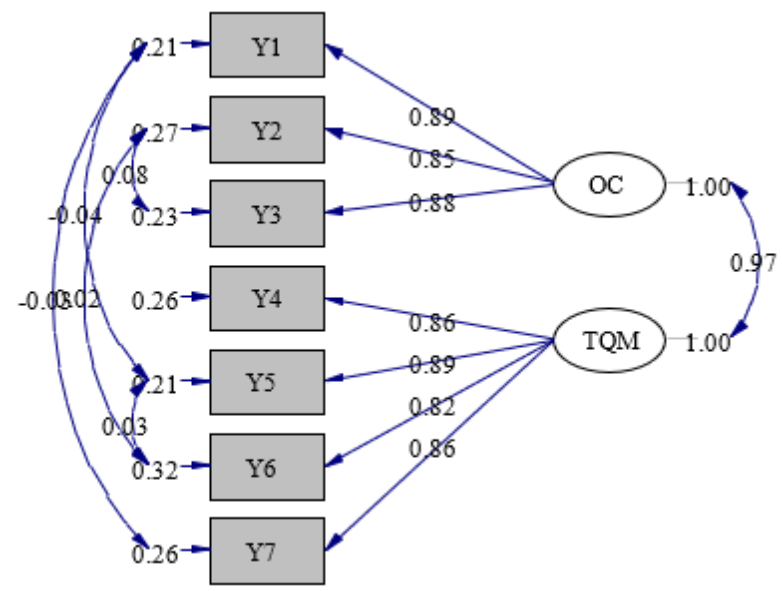

Figure 2. CFA of internal latent variables OC \& TQM $(n=500)$

Note: Chi-Square $(\chi 2)=1.91, \mathrm{df}=8, \not$ value $=0.98371, \mathrm{RMSEA}=0.000$

\subsection{Convergent model analysis}

From the analysis of the data, and the measurement of the five constructs and their hypotheses, it was determined that there was a good model fit with the empirical research data, with both convergent validity and discriminant validity being used. In structural equation modelling (SEM), CFA is usually used to access construct validity (Jöreskog et al., 2016). Hair et al. (2016) and Byrne et al. (1989) also indicated that factor loadings or regression weight estimates of latent to observed variables should have values greater than 0.50 , which indicates that all the constructs conform to the construct validity test and validity convergence.

Results in Table 6 therefore show that the $\chi^{2}$ value was 69.14 , with the ratio between $\chi^{2}$ and the $\mathrm{df}$ equal to 0.93 when tested, which showed statistical significance as it was $\geq 0.05$. This confirms the model's hypotheses were not different from the empirical data. Further confirmation was also established as the results of the goodness-of-fit index (GFI) equaled 0.98, and the AGFI equaled 0.98 (Kenny \& McCoach, 
2003). Additionally, the RMSEA was equal to 0.000amd the SRMR was equal to 0.010. As SRMR is an absolute measure of fit, a value of zero indicates a perfect fit, while a value of $<0.05$ indicates a good fit (Hu \& Bentler, 1999).

Table 6

Criteria and theory of the goodness-of-fit values

\begin{tabular}{|c|c|c|c|c|}
\hline Criteria Index & Criteria & Values & Results & Supporting theory \\
\hline Chi-square: $\chi \mathbf{2}$ & $p \geq 0.05$ & 69.14 & passed & (Rasch, 1980). \\
\hline$\chi \mathbf{2} / \mathrm{df}$ & $\leq 2.00$ & 0.93 & passed & (Byrne et al., 1989). \\
\hline GFI & $\geq 0.90$ & 0.98 & passed & $\begin{array}{c}\text { (Hair et al., 2016; Jöreskog et al., } \\
\text { 2016). }\end{array}$ \\
\hline AGFI & $\geq 0.90$ & 0.98 & passed & (Kenny \& McCoach, 2003). \\
\hline SRMR & $\leq 0.05$ & 0.010 & passed & (Hu \& Bentler, 1999). \\
\hline RMSEA & $\leq 0.05$ & 0.000 & passed & (Hu \& Bentler, 1999). \\
\hline Cronbach's Alpha & $\geq 0.70$ & $\mathbf{0 . 9 8 8}$ & passed & (Tavakol \& Dennick, 2011). \\
\hline
\end{tabular}

The validated results are detailed in Tables 7-9, as well as Figure 4.

The correlation coefficient, reliability, and AVE of the latent variables

\begin{tabular}{|c|c|c|c|c|c|}
\hline Latent variables & OC & TQM & ATT & HRM & BSC \\
\hline OC & 1.00 & & & & \\
\hline TQM & 0.937 & 1.00 & & & \\
\hline ATT & 0.881 & 0.869 & 1.00 & & \\
\hline HRM & 0.858 & 0.898 & 0.788 & 1.00 & \\
\hline BSC & 0.852 & 0.869 & 0.806 & 0.845 & 1.00 \\
\hline $\begin{array}{c}\rho_{\mathrm{C}} \text { (Construct } \\
\text { Reliability) }\end{array}$ & 0.906 & 0.919 & 0.912 & 0.962 & 0.902 \\
\hline$\rho_{\mathrm{V}}(\mathrm{AVE})$ & 0.763 & 0.740 & 0.776 & 0.668 & 0.698 \\
\hline$\sqrt{\mathrm{AVE}}$ & 0.873 & 0.860 & 0.881 & 0.817 & 0.836 \\
\hline
\end{tabular}

Note: Sig. $\leq$ 0.01, the correlation coefficient between latent variables (below the diagonal in bold), reliability of latent variables $\left(\rho_{\mathrm{C}}\right)$ and the average variance extracted (AVE).

Hypotheses testing results

\begin{tabular}{|l|c|c|c|}
\hline Hypotheses & Coef. & t-value & Results \\
\hline $\begin{array}{l}\text { H1: Attitude (ATT) has a direct positive influence on } \\
\text { organizational culture (OC). }\end{array}$ & 0.46 & $8.32^{* *}$ & consistent \\
\hline $\begin{array}{l}\text { H2: Attitude (ATT) has a direct positive influence on } \\
\text { total quality management (TQM). }\end{array}$ & 0.12 & $2.49^{*}$ & consistent \\
\hline $\begin{array}{l}\text { H3: Human resource management (HRM) has a direct } \\
\text { positive influence on organizational culture (OC). }\end{array}$ & 0.31 & $5.11^{* *}$ & consistent \\
\hline $\begin{array}{l}\text { H4: Human resource management (HRM) has a direct } \\
\text { positive influence on total quality management (TQM). }\end{array}$ & 0.30 & $3.18^{* *}$ & consistent \\
\hline $\begin{array}{l}\text { H5: Balanced scorecard (BSC) has a direct positive } \\
\text { influence on organizational culture (OC). }\end{array}$ & 0.22 & $1.97^{* *}$ & consistent \\
\hline $\begin{array}{l}\text { H6: Balanced scorecard (BSC) has a direct positive } \\
\text { influence on total quality management (TQM). }\end{array}$ & 0.11 & $6.75^{*}$ & consistent \\
\hline $\begin{array}{l}\text { H7: Organizational culture (OC) has a direct positive } \\
\text { influence on total quality management (TQM). }\end{array}$ & 0.48 & & c. \\
\hline
\end{tabular}

Note: $*$ Sig. $<0.05, * *$ Sig. $<0.01$, Critical ratios (t-values) more than 1.96 are significant at the 0.05 level. S.E. $=$ standard error, $\mathrm{CR}=$ critical ratio ( $\mathrm{t}$-value) . 
Table 9 shows the direct effect (DE), indirect effect (IE), and total effect (TE) of each construct. The direct and positive contribution of OC influences TQM the most, due to the value of 0.48.

SEM standard coefficients of influence

\begin{tabular}{|c|c|c|c|c|c|c|}
\hline \multirow{2}{*}{$\begin{array}{l}\text { Dependent } \\
\text { variables }\end{array}$} & \multicolumn{6}{|c|}{ Independent Variables } \\
\hline & & $\mathrm{R}^{2}$ & ATT & HRM & BSC & OC \\
\hline \multirow{3}{*}{$\mathrm{OC}$} & $\mathrm{DE}$ & \multirow{3}{*}{.86} & $0.46^{* *}$ & $0.31 * *$ & $0.22^{* *}$ & - \\
\hline & IE & & - & - & - & - \\
\hline & $\mathrm{TE}$ & & $0.46^{* *}$ & $0.31 * *$ & $0.22 * *$ & - \\
\hline \multirow{3}{*}{ TQM } & $\mathrm{DE}$ & \multirow{3}{*}{.89} & $0.12^{*}$ & $0.30 * *$ & $0.11 *$ & $0.48^{* *}$ \\
\hline & IE & & $0.23^{* *}$ & $0.15^{* *}$ & $0.11 *$ & - \\
\hline & $\mathrm{TE}$ & & $0.35^{* *}$ & $0.45^{* *}$ & $0.22 * *$ & $0.48^{* *}$ \\
\hline
\end{tabular}

Note: *Sig. $\leq 0.05, * *$ Sig. $\leq 0.01$, ATT $=$ attitude, HRM $=$ human resource management, BSC = balanced scorecard, $\mathrm{OC}=$ organizational culture, $\mathrm{DE}=$ direct effect, $\mathrm{IE}-$ indirect effect, $\mathrm{TE}=$ total effect

\subsection{Structural Equation Modeling (SEM) results}

Hooper et al. (2008) discussed low $\mathrm{R}^{2}$ values $(\leq 0.20)$, and suggested that they be removed from the analysis as this is an indication of high error rates. The SEM results (Figure 4) showed that the model met the required criteria as the $\mathrm{x}^{2}$ index was not statistically significant, and all the causal factors in the model were shown to have a positive influence on SRT total quality management (TQM). Ranked in importance, results determined that organizational culture (OC) had the greatest impact on total quality management (TQM=0.48), followed by human resource management $(\mathrm{HRM}=0.45)$, attitudes (ATT=0.35), and finally, the balanced scorecard $(\mathrm{BSC}=0.22)$.

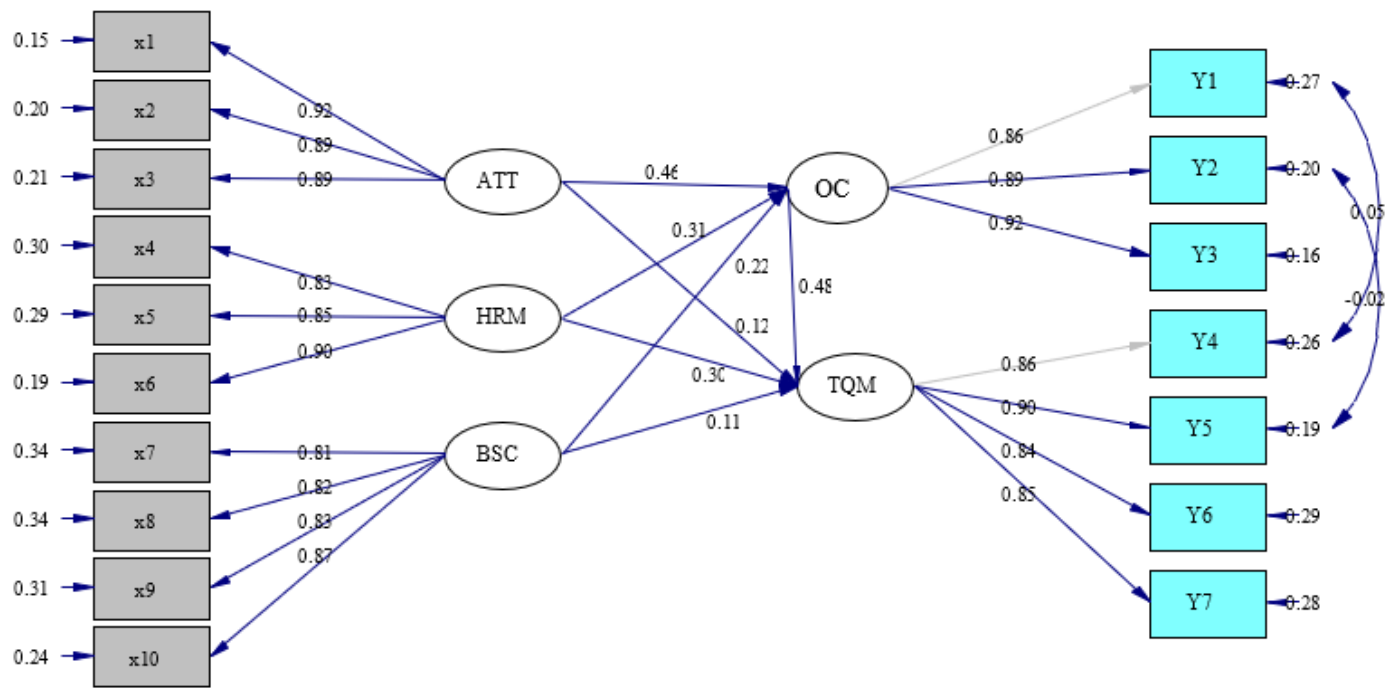

Figure 4. SEM final model with values from estimates $(\mathrm{n}=500)$

Note: Chi-Square $=69.14, \mathrm{df}=74$, -value $=0.63828$, RMSEA $=0.000$ 


\section{DISCUSSION}

Results from the study showed H1 to be supported, as staff attitude (ATT) had a direct and positive impact on SRT organizational culture (OC), with the correlation coefficient between the variables determined to be 0.46 . This is consistent with research from Tsai (2011), in which OC was significantly and positively correlated with leadership behavior and job satisfaction. Berson and Linton (2005) also determined that within research \& development $(\mathrm{R} \& \mathrm{D})$ and administrative environments, a manager's leadership behavior is closely related to work satisfaction of the employees.

Hypothesis $\mathrm{H} 2$ was also supported, which showed that ATT had a direct positive impact on TQM (0.12). This is consistent with Bradberry (2014), in which research showed that emotional intelligence (EQ) is the foundation for a host of critical skills, impacting most everything an individual says and does each day. EQ is also the single biggest predictor of performance in the workplace, and the strongest driver of leadership and personal excellence.

Concerning H3's proposed direct and positive relationship between HRM and OC, the hypothesis was supported as the correlation coefficient between the variables was determined to be 0.31 . H4 was also determined to be supported, with HRM having a direct and positive impact on TQM (0.30).

Both hypothesis $\mathrm{H} 5$ and $\mathrm{H} 6$ were also supported, with correlation coefficients between the variables BSC and OC calculated at 0.22, while the relationship between BSC and TQM was calculated to be 0.11 .

Finally, H7's relationship between OC and TQM was significantly supported as the correlation coefficients between the variables was determined to be 0.48 . This is supported by Denison (1990), in which it was concluded that working as a team competitively with a shared information base that everyone can access will unite members in pursuit of a group project, unlike when employees pursue individual projects. As such, collaboration increases employee energy, creativity, and productivity, which generally leads to less stressed, happier, and more engaged workers (Tannenbaum, 2014).

\section{CONCLUSION}

Results determined that organizational culture (OC) had the greatest impact on total quality management (TQM), followed by human resource management (HRM), attitudes (ATT), and finally, the balanced scorecard (BSC). It was also interesting to note that the survey's SRT staff judged organizational change as the most important aspect in improving efficiency (3.57), while the staff evaluation and reward system was judged to have the lowest aspect (2.88) towards a goal of TQM.

\section{IMPLICATIONS}

The study also identified several significant problems as the SRT moves forward in the $21^{\text {st }}$ century under its new 20-year master plan. These included aging staff and the pension liabilities that must be absorbed. In 2013, the Asian Development Bank reported that the SRT had pension obligations of 27\% of revenue, and the combined losses and other capital investment costs accounted for a debt burden of almost $\$ 3.2$ billion. A short-term solution for aging staff has been the hiring of consultants. However these individuals are short-term with longer term solutions yet to be found. Another solution has been a 2-year vocational work/study program in which all 120-150 participants are offered full-time employment with the SRT after their certificate completion.

Additionally, the aging work force issue was reinforced from this study's own respondents' characteristics ( $\mathrm{n}=500)$, in which $74.60 \%$ were male, and $41.20 \%$ were 51 years or older. This also raises many follow-on issues about the potential loss of expertise in the coming years and where the replacements will be found. If replacements are not found, how will junior staff be trained, or will technology replace them? 
TQM is also a fundamental change in how most enterprises manage their business, with change difficult and time consuming. SRT management must therefore lead the total quality initiative, with all employees becoming involved in TQM. As stated earlier, and as validated from numerous studies concerning Thailand's SRT, continuous quality improvement is a business imperative, and with many experienced employees nearing retirement age, an ongoing education and training process will be essential for all junior employees and new hires.

\section{REFERENCES}

Andre, T. (2017). Advances in human factors in training, education, and learning sciences. Proceedings of the AHFE 2017 International Conference on Human Factors in Training, Education, and Learning Sciences, Los Angeles, California.

Andrle, S. J. (1994). Total quality management in public transportation. Transit Cooperative Research Program, Federal Transit Administration. Retrieved from http://tinyurl.com/ybqeec8z

Arnold, J., Cooper, C., \& Robertson, I. (1995). Work psychology: Understanding human behaviour in the workplace. London, UK: Pitman Publishing.

Asian Development Bank. (2014). Thailand: Improvement of Railway Passenger Services. Retrieved from http://tinyurl.com/zgpg7ml

Berson, Y., \& Linton, J. (2005). An examination of the relationships between leadership behavior, and employee satisfaction in R\&D versus administrative environments. $R$ \& $D$ Management, 35, 51-60. doi: https://doi.org/10.1111/j.1467-9310.2005.00371.x

Best, J. W., \& Kahn, J. V. (2003). Research in education (9th ed.). Boston, MA: Allyn and Bacon.

Bradberry, T. (2014, January 9). Emotional Intelligence - EQ. Forbes Online. Retrieved from http://tinyurl.com/ybbqutqx

Byrne, B. M., Shavelson, R. J., \& Muthén, B. (1989). Testing for the equivalence of factor covariance and mean structures: The issue of partial measurement invariance. Psychological Bulletin, 105, 456-466. Retrieved from http://tinyurl.com/jixcxb6

Cameron, K. S., \& Quinn, R. E. (2006). Diagnosing and changing organizational culture: Based on the competing values framework. San Francisco, CA: Jossey-Bass.

Carmeli, A. (2003). The relationship between emotional intelligence and work attitudes, behavior and outcomes. Journal of Managerial Psychology, 18(8), 788 - 813. doi: http://dx.doi.org/10.1108/02683940310511881

Chen, F., Curran, P. J., Bollen, K. A., Kirby, J., \& Paxton, P. (2008). An empirical evaluation of the use of fixed cutoff points in RMSEA test statistic in structural equation models. Social Methods Research, 36(4), 462 - 494. doi: http:/ /dx.doi.org/10.1177/0049124108314720

Deal, T. E., \& Kennedy, A. A. (2000). Corporate cultures: The rites and rituals of corporate life. New York, NY: Perseus Publishing.

Dechawatanapaisal, D. (2005). HRM as enablers of learning work behaviour: Perspectives from Thai ICT professionals. Research and Practice in Human Resource Management, 13(1), 30 - 45. Retrieved from http://tinyurl.com/h4e3qad

Dellana, S. A., \& Hauser, R.D. (1991). Toward defining the quality culture. Engineering Management Journal, 11(2), 1115. doi: http://dx.doi.org/10.1080/10429247.1999.11415022

Denison, D. (1990). Corporate culture and organizational effectiveness. New York, NY: Wiley.

Deshpande, R., Farley, J. U., \& Webster, Jr., F. E. (1993). Corporate culture, Customer orientation, and innovativeness in Japanese firms: A quadrad analysis. The Journal of Marketing, 57(1), 23-37. doi: https://doi.org/10.2307/1252055

Economist Intelligence Unit. (2013). Challenges for human resource management and global business strategy. Retrieved from http:/ / tinyurl.com/jm63mc3

Evans, J. R. (2005). Total quality management, organization, and strategy. Nashville, TN: South-Western College Pub.

Fan, Y., Chen, J., Shirkey, G., John, R., Wu, S. R., Park, H., \& Shao, C. (2016). Applications of structural equation modeling (SEM) in ecological studies: an updated review. Ecological Processes, 5(19). doi: https://doi.org/10.1186/s13717-016-0063-3 
Ferreira, A. I., \& Hill, M. M. (2008). Organisational cultures in public and private Portuguese Universities: A case study. Higher Education, 55(6), 637-650. doi: http://dx.doi.org/10.1007/s10734-007-9080-6

Free bus, train services replaced with welfare-card system (2017, November 1). The Nation. Retrieved from https:/ / tinyurl.com/y9wanspo

Ganjanakhundee, S. (2015) Rail plan may serve China's interests more than Thailand's. The Nation. Retrieved from http://tinyurl.com/gq5ubu7

George, D., \& Mallery, P. (2010). SPSS for Windows step by step: A simple guide and reference 17.0 Update (10th Ed.). Boston, MA: Pearson.

Gimenez-Espin, J. A., Jiménez-Jiménez, D., \& Martínez-Costa, M. (2013). Organizational culture for total quality management. Total Quality Management \& Business Excellence, 24(5-6), 678-692.

doi: http://dx.doi.org/10.1080/14783363.2012.707409

Hair, J. F., Hult, G. T. M., Ringle, C. \& Sarstedt, M. (2016). A primer on partial least squares structural equation modeling (PLS-SEM). Thousand Oaks, CA: Sage.

Harre, R., \& Secord, P. (1973). The explanation of social bahaviour. Totowa, NJ: Littlefield, Adams.

Hooper, D., Coughlan, J., \& Mullen, M. (2008). Structural equation modelling: Guidelines for determining model fit. Electronic Journal of Business Research Methods, 6(1), 53-60. Retrieved from http:/ / tinyurl.com/zyd6od2

Hu, L. T., \& Bentler, P. M. (1999). Cutoff criteria for fit indexes in covariance structure analysis: Conventional criteria versus new alternatives. Structural Equation Modeling, 6(1), 1-55. doi: http://dx.doi.org/10.1080/10705519909540118

Jöreskog, K. G., Olsson, U. H., \& Fan, Y. W. (2016). Multivariate analysis with LISREL. Berlin, Germany: Springer.

Kaplan, R. S., \& Norton, D. P. (1992). The balanced scorecard-Measures that drive performance. Harvard Business Review, January-February. Retrieved from http://tinyurl.com/yapt88ym

Kaplan, R. S., \& Norton, D. P. (2001). Transforming the balanced scorecard from performance measurement to strategic management. Part I. Accounting Horizons, 15(1), 87-104. doi: https://doi.org/10.2308/acch.2001.15.1.87

Katou, A. A. (2012). Investigating reverse causality between human resource management policies and organizational performance in small firms. Management Research Review, 35(2), 134-156. doi: http://dx.doi.org/10.1108/01409171211195161

Kenny, D. A., \& McCoach, D. B. (2003). Effect of the number of variables on measures of fit in structural equation modeling. Structural Equation Modeling, 10(3), 333-51. doi: http://dx.doi.org/10.1207/S15328007SEM1003 1

Mahitthirook, A. (2017, February 25). Airport link plans to add 15 carriages. Bangkok Post. Retrieved from http://tinyurl.com/ycvry6o2

Mansouri, N., \& Goher, K. (2016). Leading different dimensions of organization performance through human resource management practices. International Journal of Human Resource Studies, 6(4), 54 - 66. Retrieved from http://tinyurl.com/zx5djck

Mertler, C. A. (2016). Introduction to Educational Research. Thousand Oaks, CA: Sage Publications.

Nigro, F, A., \& Nigro, L. G. (1984). Modern Public Administration. New York, NY: Harper and Row.

Oladapo, V. (2014). The impact of talent management on retention. Journal of Business Studies Quarterly, 5(3), 19 - 36. Retrieved from http://tinyurl.com/ja5mr8s

Prajogo, D. I., \& McDermott, C. M. (2005). The relationship between total quality management practices and organizational culture. International Journal of Operations \& Production Management, 25, 11, 1101- 1122. doi: https://doi.org/10.1108/01443570510626916

Quinn R. E., \& Rohrbaugh J. (1983). A spatial model of effectiveness criteria: Towards a competing values approach to organizational analysis. Management Science, 29(3), 363-377. doi: https://doi.org/10.1287/mnsc.29.3.363

Quinn R. E. (1988). Beyond rational management: Mastering the paradoxes and competing demands of high performance. San Francisco, CA: Jossey-Bass.

Rasch, G. (1980). Probabilistic models for some intelligence and attainment tests. Chicago, IL: University of Chicago Press.

Reeve, E. M. (2016). 21st century skills needed by students in technical and vocational education and training (TVET). Asian International Journal of Social Sciences, 16(4), 65 - 82. doi: https://doi.org/10.29139/aijss.20160404

Smith, K. (2017, September 25). Thailand unveils \$US 81 bn rail development plan. International Railway Journal. Retrieved from http://tinyurl.com/y7elaxkv 
Soderberg, M., Kalagnanam, S., Sheehan, N. T., \& Vaidyanathan, G. (2011). When is a balanced scorecard a balanced scorecard? International Journal of Productivity and Performance Management, 60(7), 688-708. doi: https://doi.org/10.1108/17410401111167780

Sornsaruht, P., \& Deebhijarn, S. (2016). Free train transportation in Thailand: A financial SWOT analysis on its social impact. Asian International Journal of Social Sciences, 16(1), 11 - 33. doi: https://doi.org/10.29139/aijss.20160102

Srimalee, S. (2017, January 6). Infrastructure plan to change logistics landscape, boost property developers. The Nation. Retrieved from http://tinyurl.com/yd2e3u27

Tannenbaum, N. (2014, September 18). Leadership challenge: Creating a collaborative organizational culture. UNC Kenan-Flagler Business School. Retrieved from http://tinyurl.com/y7mydbyo

Tansawat, T., Kanitpong, K., Kishi, K., Utainarumol, S., \& Jiwattanakulpaisarn, P. (2015). The impact of public transport subsidy on social inclusion: The case of free train policy in Thailand. Journal of the Eastern Asia Society for Transportation Studies, 11, 2558-2574. http://doi.org/10.11175/easts.11.2558

Tavakol, M., \& Dennick, R. (2011). Making sense of Cronbach's alpha. International Journal of Medical Education, 2, 53 55. doi: http://dx.doi.org/10.5116/ijme.4dfb.8dfd

ThaiPBS. (2018, February 17). Govt urged to ease hiring freeze on SRT to solve train driver shortage. Retrieved from https://tinyurl.com/ybdhl2tq

Tsai, Y. (2011). Relationship between organizational culture, leadership behavior and job satisfaction. BMC Health Services Research, 11, 98. doi: http://dx.doi.org/10.1186/1472-6963-11-98

Tseng, Y-y., Yue, W. L., \& Taylor, M. A. P. (2005). The role of transportation in logistics chain. Proceedings of the Eastern Asia Society for Transportation Studies, 5, 1657 - 1672. Retrieved from http:/ / tinyurl.com/ycm4m632

Ullman, J. B. (2001). Structural equation modeling. In B. G. Tabachnick \& L. S. Fidell (Eds.). Using Multivariate Statistics (4th ed.). Needham Heights, MA: Allyn and Bacon.

Wong, K.K-K (2013). Partial least squares structural equation modeling (PLS-SEM) techniques using SmartPLS. Marketing Bulletin, 24. Retrieved from http://tinyurl.com/ybw7xvr3

$\mathrm{Zu}$, X., Robbins, T. L., \& Fredendall, L. D. (2009). Mapping the critical links between organizational culture and TQM/Six Sigma practices, International Journal of Production Economics, 123(1), 86-106.

doi: https://doi.org/10.1016/i.ijpe.2009.07.009 